\title{
Heterotrophic growth of Aphanothece microscopica Nägeli in calcium alginate beads from BG11 medium and vinasse
}

\section{Cultivo heterotrófico de Aphanothece microscopica Nägeli imobilizada em alginato de cálcio a partir de meio BG11 e vinhaça}

\author{
Reinaldo Gaspar Bastos ${ }^{1}$; Bruna Harumi Ogata ${ }^{2}$; Victor de Carvalho Matos ${ }^{3}$; \\ Geise Cristina de Jesus ${ }^{4}$; Mariana Altenhofen da Silva ${ }^{5}$
}

\begin{abstract}
The application of microalgae immobilized in the treatment of wastewater has increased in recent years with emphasis mainly on the simultaneous removal of carbon and nitrogen, besides other nutrients such as phosphorus. As for the cellular immobilization methods, the encapsulation system in matrices of macromolecules such as alginate has aroused interest due to its characteristics of biodegradability, biocompatibility and non-toxicity. In this context, the objective of the research was the development of alginate beads for the immobilization of the cyanobacterium Aphanothece microscopica Nägeli , as well as the evaluation of growth and ability to remove glucose, as example of organic compound, from the liquid "bulk" phase. Results indicate the higher specific growth feasibility of heterotrophic growth of immobilized cyanobacteria Aphanothece microscopica Nägeli on calcium alginate beads from BG11 medium and sugarcane vinasse, with perspective of continuous removal of organic matter from wastewaters by this microalgae growth system.
\end{abstract}

Keywords: Aphanothece. Cyanobacterium. Sugarcane vinasse. Calcium alginate. Immobilization.

\section{Resumo}

A aplicação de microalgas e cianobactérias imobilizadas no tratamento de efluentes tem sido objeto de diversas pesquisas nos últimos anos, visando principalmente a remoção de carbono e nitrogênio simultaneamente, além de outros nutrientes como fósforo. Quanto aos métodos de imobilização de microalgas, o sistema de encapsulação em matrizes de macromoléculas como o alginato tem despertado interesse devido às suas características de biodegradabilidade, biocompatibilidade e não toxicidade. Neste contexto, o objetivo da pesquisa foi o desenvolvimento de esferas de alginato para a imobilização da cianobactéria Aphanothece microscopica Nägeli, bem como a avaliação do crescimento e capacidade de remoção de glicose, como exemplo de composto orgânico, da fase líquida "bulk". Os resultados indicaram elevadas velocidades específicas de crescimento para Aphanothece microscopica Nägeli imobilizada em alginato de cálcio tanto para o meio BG11 e vinhaça de cana-de-açúcar, sugerindo a viabilidade do processo, com perspectivas de remoção contínua de matéria orgânica de efluentes a partir deste sistema de cultivo microalgal.

Palavras-chave: Aphanothece. Cianobactéria. Vinhaça. Alginato de cálcio. Imobilização.

\footnotetext{
${ }^{1}$ Prof. Dr., Depto. de Tecnologia Agroindustrial e S.E. Rural, CCA, UFSCar, Araras, SP, Brasil; Email: reinaldo.bastos@ufscar.br

${ }^{2}$ Graduação em Biotecnologia, CCA, UFSCar, Araras, São Paulo, Brasil; Email: bruna.ogata@ usp.br

${ }^{3}$ Graduação em Engenharia Agronômica, CCA, UFSCar, Araras, SP, Brasil; Email: vitorcarmatos@gmail.com

${ }^{4}$ Me. em Prod. Vegetal e Bioprocessos (PVBA), CCA, UFSCar, Araras, SP, Brasil; Email: geisecrj@gmail.com

${ }^{5}$ Profa. Dra., Depto. de Tecnologia Agroindustrial e S.E. Rural, CCA, UFSCar, Araras, SP, Brasil; Email: mariana.alt@ufscar.br
} 


\section{Introduction}

Cell immobilization is a series of techniques used to maintain microorganisms confined by physical or chemical interactions in a solid matrix or fixed in the surface of the immobilizing agent. Microbial immobilized should be preserves the metabolic activity of living cells or enzymes in order to improve the productivity of the involved bioprocesses and reduce the costs of laboratory and industrial operations (GIESE, 2015). The advantages of using immobilized systems to free-cell suspensions are the possibility of using high cellular concentrations, continuous processes with reuse cells, high volumetric productivity, with protecting the cells from damages caused by environmental stress such as high concentrations of substrate, $\mathrm{pH}$ and shear stress. Particularly, cyanobacteria immobilized in matrices may benefit a biotechnological process, either in the production of a specific metabolite or in the removal of wastewater pollutants (DEBASHAN, BASHAN, 2010). Cyanobacteria have been used for many years for chemical oxygen demand (COD), nitrogen, and phosphorus removal from industrial and urban wastewater with cells in suspension or immobilized (DE-BASHAN; BASHAN, 2010; VIEIRA et al., 2012; BASTOS et al., 2014; MATTOS; BASTOS, 2015).

The method of immobilization of entrapment is widely used because of its ease, low toxicity and high cellular retention capacity. The technique consists of the physical confinement of a cell population in a hydrophilic gelforming polymeric matrix. The pores of the formed matrix are smaller than the cells contained therein. The most widely used materials for the production of the gel particles are the natural polymers agar, k-carrageenan, alginate and pectin. The major drawback of the immobilization technique by wrapping is the limitation imposed by intra particular diffusion of substrates and metabolic products. The particle size, the diffusivity of the species through the polymer matrix and the cell concentration in the particle should be optimized in order to minimize these effects (PRADELLA, 2001).

Calcium alginate is the polymer matrix most commonly used to immobilize microalgae and maintain high cell viability for long periods. However, the matrix is fragile in the presence of chelating agents present in the wastewater, such as phosphate and citrate, which affect the stability of the matrix, leading to the disintegration and dissolution (JIMENEZ-PEREZ et al., 2004). The deterioration of alginate spheres due to several factors such as $\mathrm{pH}$ and wastewater composition is still a concern (DRAGET;
SKJAK-BRAEK; SMIDSROD, 1997). However, hypothetically, the degradation of biopolymers beads immersed over a long time in wastewater, such as vinasse, is mainly a result of the biological activity of heterotrophic bacteria that have the capacity to degrade the alginate and not the nutrients present in the wastewater, after the secondary effluent treatment. As the degradation of the beads is relatively slow, the culture time is sufficient to efficiently remove nutrients by microorganisms immobilized in the particles (CRUZ et al., 2013).

Sodium alginate is a hydrophilic colloidal polysaccharide extracted from several species of brown algae (Phaeophyceae) with dilute alkali solutions. The structure of alginic acid consists of linear chains of residues of $\beta$-D-manuronic (M) and $\alpha$-L-guluronic (G) acids, covalently bound with $(1 \rightarrow 4)$ type bonds (LIAKOS et al., 2013). These residues are arranged in the form of MM or GG blocks, or alternatively linked (MG blocks), having a widely varying composition and sequence, depending on the source of the alginate (GARCIA-CRUZ; FOGGETTI; SILVA, 2008).

Alginate immobilization occurs by crosslinking the carboxyl groups present in the alginate chain with polyvalent cations, with calcium chloride being the most used crosslinking agent. Monovalent cations and $\mathrm{Mg}^{+2}$ ions do not result in gel formation. The carboxyl groups of adjacent alginate chains react with the calcium ions to form a three-dimensional polymer network (DRAGET; SKJAK-BRAEK; SMIDSROD, 1997). The mechanism that best describes the formation of alginate gels in the presence of calcium ions is known as model "egg-box".

Vinasse is the main wastewater from ethanoldistillation fermentation from sugarcane processing. In the 2016/2017, from sugarcane harvesting in Brazil, 26 billion liters of ethanol were produced (JESUS, 2018), and, consequently, about $10 \mathrm{~L}$ of vinasse are obtained for each liter of ethanol (FREIRE; CORTEZ, 2000; CHRISTOFOLETTI et al., 2013; MORAIS; BASTOS, 2018). Vinasse is rich in organic compounds, nitrogen, phosphorous, and ions (e.g., $\mathrm{K}^{+}, \mathrm{Ca}^{+2}, \mathrm{Mg}^{+2}$,) and such nutrients could be incorporated into the microalgal biomass to maintain growth and produce high-value compounds (SPOLAORE et al., 2006; SILVA et al., 2017). Vinasse has been used can promote improvement in soil fertility if the quantities not exceed their ion retention capacity, depending on the soil characteristics (JESUS, 2018; BETTANI et al., 2019).

Aphanothece microscopica Nägeli is a cyanobacterium Chorococcaceae that forms blue-green colonies 
(approximately $9.0-9.5 \mu \mathrm{m}$ by $4.0-4.2 \mu \mathrm{m}$ ), that has been studied for wastewater treatment, valorization of residues, single-cell protein and phycocyanin production (JACOB-LOPES et al., 2006; JACOB-LOPES et al., 2007; JACOB-LOPES; LACERDA; FRANCO, 2008; ZEPKA et al., 2010; BASTOS et al., 2014; MORAIS; BASTOS, 2018).

Although the cyanobacteria present the photosynthesis as preferential metabolism, several strains can assimilate organic compounds by heterotrophic growth in the dark using simple organic molecules such as acetate, glucose, and organic acids (FAY, 1983; QUEIROZ et al., 2007). According to Perez-Garcia et al., (2011), the heterotrophic growth approach eliminates the limitation of light-autotrophic microalgae production, allowing the use of practically any bioreactor with wastewaters.

In this context, the present worked aimed to evaluate the heterotrophic growth of Aphanothece microscopica Nägeli in calcium alginate beads from standard BG11 medium and vinasse.

\section{Material and methods}

\section{Inoculum and medium}

Inoculum of Aphanothece microscopica Nägeli was propagated and maintained on BG11 medium (RIPKA et al., 1979) in $\mathrm{gL}^{-1}: \mathrm{K}_{2} \mathrm{HPO}_{4}$ (0.030), $\mathrm{MgSO}_{4} .7 \mathrm{H}_{2} \mathrm{O}$ (0.075), $\mathrm{CaCl}_{2} .2 \mathrm{H}_{2} \mathrm{O}$ (0.036), $\mathrm{C}_{6} \mathrm{H}_{8} \mathrm{FeNO}_{7}$ (0.0060), $\mathrm{Na}_{2}$ EDTA (0.001), $\mathrm{C}_{6} \mathrm{H}_{8} \mathrm{O}_{7} . \mathrm{H}_{2} \mathrm{O}$ (0.0060), $\mathrm{Na}_{2} \mathrm{CO}_{3}$ (0.020), $\mathrm{NaNO}_{3}$ (150), $\mathrm{NaCl}$ (0.072), $\mathrm{H}_{3} \mathrm{BO}_{3}$ (2.860), $\mathrm{MnCl}_{2} .4 \mathrm{H}_{2} \mathrm{O}$ (1.810), $\mathrm{ZnSO}_{4} .7 \mathrm{H}_{2} \mathrm{O}$ (0.222), $\mathrm{Na}_{2} \mathrm{MoO}_{4} .2 \mathrm{H}_{2} \mathrm{O}$ (0.390), $\mathrm{CuSO}_{4} .5 \mathrm{H}_{2} \mathrm{O}$ (0.079), $\mathrm{CoCl}_{2} \cdot 6 \mathrm{H}_{2} \mathrm{O}(0.040)$ and $\mathrm{pH}$ 7.5. The cultures were propagated and maintained at the Laboratory of Applied Microbiology and Control (LABMAC/CCA/UFSCar) with a 12:12 h (light:darkness) photoperiod with 2 klux.

The sugarcane vinasse used in the experiments was collected from a Sugarcane Processing Industry located in Araras, São Paulo, Brazil, being stored in plastic bottles and kept in the freezer.

Immobilization of cells in alginate beads Sodium alginate solution was prepared by dissolving $7.0 \mathrm{~g}$ of the polymer in $200 \mathrm{~mL}$ of distilled water and calcium chloride solution from $5 \mathrm{~g}$ in $200 \mathrm{~mL}$. Both solutions were autoclaved $\left(121^{\circ} \mathrm{C} / 20 \mathrm{~min}\right)$ and left at room temperature to cool. $71 \mathrm{~mL}$ of the alginate solution were thoroughly homogenized with $29 \mathrm{~mL}$ of the inoculum. This proportion was based on the initial cell count in the inoculum, around $10^{6}$ cells per gram of beads.
With the aid of a $20 \mathrm{~mL}$ syringe, the mixture was dripped into $100 \mathrm{~mL}$ of the calcium chloride solution and the beads were allowed to stand in $\mathrm{CaCl}_{2}$ for at least 12 hours to be consistent, collected by filtration and rinsed with deionized water.

\section{Experiments}

In the cells growth by BGN medium supplemented with glucose, $50 \mathrm{~mL}$ of beads were added in $250 \mathrm{~mL}$ Erlenmeyers Flasks already containing $100 \mathrm{~mL}$ of BGN medium added with $10 \mathrm{~g}$ of glucose. The flasks were covered to prevent light imminence and allows heterotrophic cultures, under constant stirring (100 rpm) and $25^{\circ} \mathrm{C}$ in the dark, for until 30 hours. The experiments were made in triplicate. The beads were allowed to stand in the medium and samples were taken for analysis of the size and stability of the spheres produced and for counting cells inside the beads and in the liquid phase.

Samples were periodically taken to perform the counting of cells inside the beads and in the liquid and to analyze the consumption of glucose by the cyanobacteria. Counting was performed inside and outside spheres (bulk phase). For inside, each bead was added $1 \mathrm{~mL}$ of the citrate solution with subsequent homogenization on a tube shaker and the counting was done using Neubauer Chamber. Glucose content in bulk phase (BG11 medium) were determined by the enzymatic glucose oxidase - peroxidase method with LABORLAB $®$ kit.

For the experiments from vinasse, this wastewater was previously autoclaved at $121{ }^{\circ} \mathrm{C}$ for 10 minutes, with the $\mathrm{pH}$ adjusted to 7.6. A volume of $50 \mathrm{~mL}$ of beads (without the $\mathrm{CaCl} 2$ solution) was added to $100 \mathrm{~mL}$ of vinasse, and the flasks were covered to prevent light incidence. Samples were taken periodically for verify if the stability of the beads, cell counting inside and outside particles, and glucose content in bulk phase (vinasse) were determined by the enzymatic glucose oxidase - peroxidase method with $\mathrm{LABORLAB} \otimes$ kit.

The kinetics parameters were determined based on equations described by Doran (2000). The maximum specific growth rate $\left(\mu_{\max }\right)$ was estimated in the exponential growth phase according to equation (1),

$$
\mu_{\max }=\frac{\ln \left(\frac{X_{1}}{X_{0}}\right)}{t_{1}-t_{0}}
$$

where $X_{0}$ and $X_{1}$ represent the cell concentration at the beginning and the end of the log-phase, respectively; $t_{0}$ and $t_{1}$ represent the log-phase period. 


\section{Results}

Figure 1 shows the variation of the normalized bead diameter (ratio between the diameter at the time and initial) during the growth of the immobilized cells with liquid phase "bulk" the BG11 standard medium and sugarcane vinasse.

Figure 1 - Normalized bead diameter during cell growth in BG11 medium with glucose (o) and sugarcane vinasse (口)

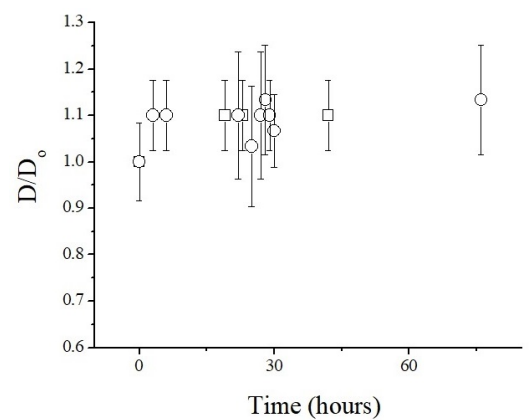

Source: The authors

The results indicate a discrete increase of the diameter for both conditions due to the swelling of the particles, suggesting an adequate mechanical resistance in the 72 experimental hours. The variation of the diameter of the spheres may be related to the degree of swelling of the matrix. This property is important because modifications in the polymer matrix caused by swelling will influence the diffusivity of the nutrients through the spheres (JESUS, 2018).

Figures 2 and 3 present the growth curves for Aphanothece microscopica Nägeli immobilized and free cells with bulk phase BG11 medium with glucose and sugarcane vinasse.

Figure 2 - Growth curves of Aphanothece microscopica Nägeli immobilized cells from BG11 medium with glucose (०) and sugarcane vinasse ( $\square$ )

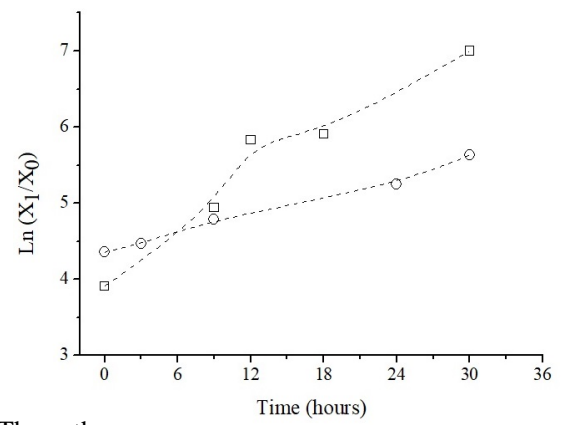

Source: The authors.

It was observed specific growth rate superior in vinasse $\left(0.12 \mathrm{~h}^{-1}\right)$ when compared to the BG11 medium with addition of glucose, as can be verified in Table 1 .
Figure 3 - Growth curves of Aphanothece microscopica Nägeli free cells from BG11 medium with glucose (o) and sugarcane vinasse ( $\square$ )

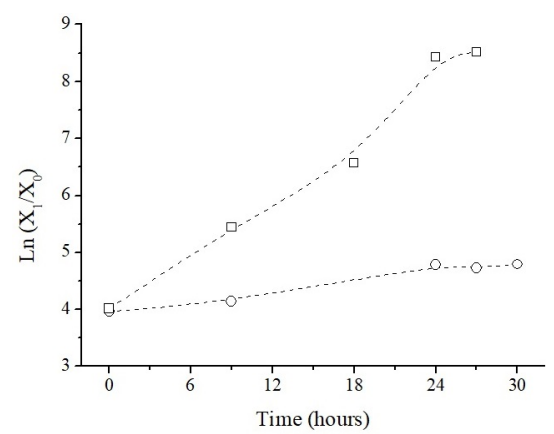

Source: The authors.

Table 1 - Maximum specific growth rates $\left(\mu_{\max }\right)$ for cultivation of Aphanothece microscopica Nägeli immobilized cells from BG11 medium with glucose and sugarcane vinasse

\begin{tabular}{ccc}
\hline Growth condition & $\mu_{\max }\left(h^{-1}\right)$ & $R^{2}$ \\
\hline BG11 medium + Glucose & $0.04 \pm 0.002$ & 0.9824 \\
Vinasse & $0.12 \pm 0.007$ & 0.9081
\end{tabular}

$R^{2}$ : determination coefficient for linear fit in the semi-log growth plot Source: The authors.

Table 2 shows the specific growth rates for the dispersed microbial population in the liquid phase of the system, i.e. refers to cells that were not immobilized efficiently. In fact, for these microorganisms, the addition of glucose led to higher specific growth rates in vinasse $\left(0.17 \mathrm{~h}^{-1}\right)$, since this substrate is suspended in the medium together with the cyanobacteria, requiring no diffusion into the interior of the particles.

Table 2 - Maximum specific growth rates for Aphanothece microscopica Nägeli cells in bulk phase

\begin{tabular}{ccc}
\hline Growth condition & $\mu_{\max }\left(h^{-1}\right)$ & $R^{2}$ \\
\hline BG11 medium + Glucose & $0.03 \pm 0.002$ & 0.9629 \\
Vinasse & $0.17 \pm 0.007$ & 0.9735 \\
\hline
\end{tabular}

$R^{2}$ : determination coefficient for linear fit in the semi-log growth plot Source: The authors.

Comparing the Tables it is verified that the kinetic data differ more when using vinasse in comparison to the BGN medium. This suggests that the loss of cells to the medium occurs more intensely when vinasse is used, which causes the growth to be more pronounced in the liquid phase.

However, this information is interesting in terms of process development, since the immobilized biomass grows and can be separated and used with greater ease, while the biomass that develops outside the particles is responsible for the removal of compounds and the wastewater. Thus, it 
is identified that, regardless of the form of cultivation (free or immobilized), the "bulk" nutrient phase determined the highest specific growth rates.

Because it is a wastewater, the chemical composition of the vinasse is very variable and will depend on the composition of the wine to be distilled, the raw material and the ethanol-fermentation process. However, in general, it is composed of high levels of organic carbon and salts (FREIRE; CORTEZ, 2000).

Thus, this medium would allow a more suitable heterotrophic growth for the free and immobilized cyanobacteria. Under some heterotrophic growth conditions, the microalgal biomass yields are consistent and reproducible, reaching cells densities of dry biomass per liter much higher than the maximum cell biomass from autotrophic cultures (PEREZ-GARCIA et al., 2011).

About organic carbon removal, Figure 4 shows up to $70 \%$ of glucose consumption at 30 hours. Moreover, it is observed the initial glucose consumption by zeroorder reaction (non-limiting conditions), suggesting that there was no diffusional limitation of glucose into the particles. As already reported in the literature, part of this carbon removal may be due to the biosorption of compounds in the particles (MORENO-GARRIDO, 2008)

Figure 4 - Glucose profile during Aphanotheces growth immobilized on alginate beads from sugarcane vinasse ( $\square$ )

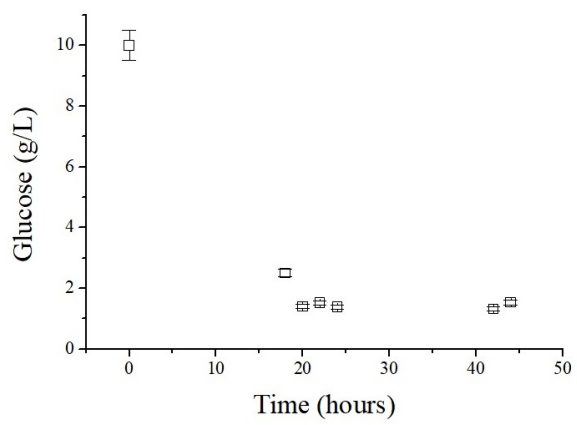

Source: The authors

As biopolymers are capable of absorbing nutrients, they can thus increase the efficiency of immobilized cells used in the treatment of effluents (JESUS, 2018). As the structure of the alginate gel is governed by the kinetics of formation, it affects the diffusion of solutes in the beads, leading to a removal of compounds from the bulk phase.

\section{Conclusions}

Results indicate the feasibility of heterotrophic growth of immobilized cyanobacteria Aphanothece microscopica Nägeli on calcium alginate beads from BG11 medium and vinasse.
The cell growth kinetic and glucose removal indicate a perspective of continuous removal of organic matter and nutrients from vinasse and other wastewaters, keeping the microalgae immobilized in bioreactor.

\section{References}

BASTOS, R. G.; BONINI, M. A.; ZEPKA, L. Q.; JACOBLOPES, E.; QUEIROZ, M. I. Treatment of rice parboiling wastewater by cyanobacterium Aphanothece microscopic Nägeli with potential for biomass products. Desalination and Water Treatment, Hopkinton, v. 53, p. 1-7, 2014.

BETTANI, S. R.; RAGAZZO, G. O.; SANTOS, N. L.; KIECKBUSCH, T. G.; BASTOS, R. G.; SOARES, M. R.; SILVA, M. A. Sugarcane vinasse and microalgal biomass in the production of pectin particles as an alternative soil fertilizer. Carbohydr. Polym., Aveiro, v. 203, p. 322-330, 2019.

CHRISTOFOLETTI, C. A.; ESCHER, J. P.; CORREIA, J. E.; MARINHO, J. F. U.; FONTANETTI, C. S. Sugarcane vinasse: environmental implications of its use. Waste Management, Houston, v. 33, p. 2752-276, 2013.

CRUZ, I.; BASHAN, Y; HERNÀNDEZ-CARMONA, G.; DE-BASHAN, L. G. Biological deterioration of alginate beads containing immobilized microalgae and bacteria during tertiary wastewater treatment. Applied Microbiology and Biotechnology, Berlin, v. 97, p. 9847-9858, 2013.

DE-BASHAN L. E.; BASHAN, Y. Immobilized microalgae for removing pollutants: review of practical aspects. Bioresource Technology, Essex, v. 101, p. 1611-1627, 2010 .

DORAN, P. Engineering principles for bioprocess. Cambridge: Academic Press, 2000.

DRAGET, K. I.; SKJAK-BRAEK, G.; SMIDSROD, O Alginate based new materials. Int. Journal of Biological Macromolecules, Guildford, v. 21, p. 47-55, 1997.

FAY, P. The blue-greens (Cyanophyta-cyanobacteria). London: Edward Arnold, 1983.

FREIRE, W. J.; CORTEZ, L. A. B. Vinhaça de cana-deaçúcar. Guaíba: Livraria e Editora Agropecuária, 2000. (Série Engenharia Agrícola, v. 1).

GARCIA-CRUZ, C. H.; FOGGETTI, U.; SILVA, A. N. Alginato bacteriano: aspectos tecnológicos, características e produção. Química Nova, SP, v. 31, p. 1800-1806, 2008. 
GIESE, E. C. Potencial biotecnológico do uso de microorganismos imobilizados em gel de alginato de cálcio. Rio de Janeiro: CETEM/MCTI, 2015. (Série Tecnologia Ambiental).

JACOB-LOPES, E.; LACERDA, L. M. C. F.; FRANCO, T. T. Biomass production and carbon dioxide fixation by Aphanothece microscopic Nägeli in a bubble column photobioreactor. Biochemical Engineering Journal, Amsterdam, v. 40, p. 27-34, 2008.

JACOB-LOPES, E.; ZEPKA, L. Q.; PINTO, L. A. A.; QUEIROZ, M. I. Characteristics of thin-layer drying of the cyanobacterium Aphanothece microscópica Nägeli. Chemical Engineering and Processing, [S. 1.], v. 46, p. 63-69, 2007.

JACOB-LOPES, E.; ZEPKA, L. Q.; QUEIROZ, M. I.; NETTO, F. M. Caracterização da fração proteica da cianobactéria Aphanothece microscópica Nägeli cultivada no efluente da parboilização do arroz. Ciênc. Tecnol. Aliment., Campinas, v. 26, p. 482-488, 2006.

JESUS, G. C. Desenvolvimento de matrizes poliméricas de alginato e pectina para o cultivo de células imobilizadas de Desmodesmus subspicatus em vinhaça de cana-deaçúcar. 2018. Dissertação (Mestrado em Produção Vegetal e Bioprocessos Associados) - Universidade Federal de São Carlos, São Paulo, 2018.

JIMENEZ-PEREZ, M. V.; SÁNCHEZ-CASTILLO, P.; ROMERA, O.; FERNÁNDEZ-MORENO, D.; PÉREZMARTÍNEZ, C. Growth and nutrient removal in free and immobilized planktonic green algae isolated from pig manure. Enzyme and Microbial Technology, Guildford, v. 34, p. 392-398, 2004.

LIAKOS, I.; RIZZELLO, L.; SCURR, D. J.; POMPA, P. P.; BAYER, I. S.; ATHANASSIOU, A. All-natural composite wound dressing films of essential oils encapsulated in sodium alginate with antimicrobial properties. International Journal of Pharmaceutics, Amsterdam, v. 463, p. 137-145, 2013.

MATTOS, L. F. A.; BASTOS, R. G. COD and nitrogen removal from sugarcane vinasse by heterotrophic green algae Desmodesmus sp. Desalination and Water Treatment, Hopkinton, v. 57, p. 9465-9473, 2015.

MORAIS, D. V.; BASTOS, R. G. Phycocyanin production by Aphanothece microscopica Nägeli in synthetic medium supplemented with sugarcane vinasse. Applied Biochemistry and Biotechnology, Clifton, v. 186, p. 1-11, 2018.
MORENO-GARRIDO, I. Microalgae immobilization: current techniques and uses. Bioresource Technology, Essex, v. 99, p. 3949-3964.

PEREZ-GARCIA, O.; ESCALANTE F. M.; DEBASHAN L. E.; BASHAN Y. Heterotrophic cultures of microalgae: metabolism and potencial products. Water Research, New York, v. 45, p. 11-36, 2011.

PRADELLA, J. G. C. Reatores com células imobilizadas. In: SCHIMIDELL, W.; LIMA, U. A.; AQUARONE, E., BORZANI, W. Biotecnologia Industrial. São Paulo: Edgard Blücher Ltda, 2001. v. 2.

QUEIROZ, M. I.; JACOB-LOPES, E.; ZEPKA, L. Q.; BASTOS, R. G.; GOLDBECK, R. The kinetics of the removal of nitrogen and organic matter from parboiled rice effluent by cyanobacteria in a stirred batch reactor. Bioresource Technology, [S. 1.], v. 98, p. 2163-2169, 2007.

RIPKA, R.; DERUELLES, J.; WATERBURY, J. B.; HERDMAN, M.; STANIER, R. Y. Generic assignments strain histories and properties of pure cultures of cyanobacteria. Journal of General Microbiology, London, v. 111, p. 1-61, 1979.

SILVA, M. A.; BARBOSA, G. H.; CODATO, C. B.; MATTOS, L. F. A.; BASTOS, R. G.; KIECKBUSCH, T. G. Heterotrophic growth of green microalgae desmodesmus subspicatus in ethanol distillation wastewater (vinasse) and lipid extraction with supercritical $\mathrm{CO}_{2}$. J. Chemical Technology Biotechnology, [S. 1.], v. 92, p. 573-579, 2017.

SPOLAORE, P.; CASSAN, C. J.; DURAN, E.; ISAMBERT, A. Commercial Applications of Microalgae. Journal of Bioscience and Bioengineering, v. 101 (2), p. 87-96, 2006.

VIEIRA, J. G.; SILVA MANETTI, A. G.; JACOB-LOPES, E.; QUEIROZ, M. I. Uptake of phosphorus from dairy wastewater by heterotrophic cultures of cyanobacteria. Desalination and Water Treatment, Hopkinton, v. 40, p. 224-230, 2012.

ZEPKA, L. Q.; JACOB-LOPES, E.; GOLDBECK, R.; SOUZA-SOARES, L. A.; QUEIROZ, M. I. Nutritional evaluation of single-cell protein produced by Aphanothece microscopic Nägeli, Bioresource Technology, [S. 1.], v. 101, p. 7107-7111, 2010.

Received: July 5, 2019 Accepted: Nov. 5, 2019 